\title{
EXPERIMENTAL STUDIES OF GRANULATED BLAST FURNACE SLAG
}

\author{
${ }^{1}$ Hana OVČAČÍKOVÁ, ${ }^{1}$ Marek VELIČKA, ${ }^{1}$ Petra MAIEROVÁ, ${ }^{1}$ Jozef VLČEK, ${ }^{2}$ Jitka HALAMOVÁ \\ 1VSB - Technical University of Ostrava, Ostrava, Czech Republic, EU, hana.ovcacikova@vsb.cz \\ ${ }^{2}$ Liberty Ostrava a.s, Ostrava, Czech Republic, EU, jitka.halamova@libertysteelgroup.com
}

https://doi.org/10.37904/metal.2020.3450

\begin{abstract}
Blast furnace slag is generated as a by-product of the metallurgical industry and can be called "multifunctional waste". It can be used in the building industry, reused in production or landfilled. Recovery of waste brings both economical and ecological benefits. Granulated blast furnace slag (GBFS) has a variable chemical composition and belongs to the group of so-called latent hydraulic materials. Alkaline activation (AA) is followed by the formation of $\mathrm{CSH}$ phases, which are an effective product of chemical processes in the mixture. GBFS is commonly activated by a liquid activator. This experiment focused on alkaline activation of GBFS with the use of liquid (water glass) and with a solid alkaline activator $\left(\mathrm{Na}_{2} \mathrm{SiO}_{3}\right)$ with treatment silicate modulus $\mathrm{Ms}=1$. GBFS was characterized by X-ray powder diffraction (XRD), X-ray fluorescence spectroscopy (XRF), granulometry (PSD), thermogravimetric analysis (TG) and differential thermal analysis (DTA). The samples were evaluated in terms of their compressive strength and bulk density after 2, 7 and 28 days of hydration. Annealing loss and bulk density of original GBFS were determined at $\Delta 100, \Delta 200$ and $\Delta 300^{\circ} \mathrm{C}$.
\end{abstract}

Keywords: Metallurgy, slag, alkali activation, hydration

\section{INTRODUCTION}

Based on data about steel production released by the World Steel Association (WSA), steel production in 2019 was 1,870 Tg worldwide, China accounting for 996M and the Middle East 45.3 Tg [1]. Iron and steel production bring about large quantities of waste of different chemical composition. Around $50 \%$ of metallurgical waste worldwide is recycled and part of these products is suitable for the construction industry. There is growing interest in the secondary important product slag, which is a by-product of iron and steel production. The value of slag has increased dramatically. Slag producers want a larger share of this value, so that prices have also increased accordingly. This by-product is widely used as supplementary cement based material (SCM) in the production of cement and concrete because of its latent hydraulic properties and certain pozzolanic properties [2,3]. 4.1 billion metric tons of cement were produced worldwide and 88.5 million metric tons were produced in the US in 2019 [4]. Nowadays, countries around the world are starting to produce non-clinker components in cement (some of the emirates in the UAE now stipulate at least $60 \%$ fly ash or slag in cement). Several alternatives such as alkali-activated cement, calcium sulphoaluminate cement, magnesium oxy carbonate cement (carbon negative cement), supersulphated cement etc. are being made with the advantages of Portland cement [5]. After the closure of coal-fueled power stations, particularly in the US and EU, fly ash supplies are effectively reducing: slag is the next 'go-to'. Around $75 \%$ of globally-produced blast furnace slag (BFS) is granulated, creating around $250 \mathrm{Tg}$ of GBFS, for example $150 \mathrm{Tg}$ in China, $30 \mathrm{Tg}$ in Japan and $70 \mathrm{Tg}$ in the world. GGBS is very fine, forming glassy texture. It has the potentional to partially replace cement. Their use of $40 \%$ in concrete reduces $\mathrm{CO}_{2}$ emissions by about $22 \%$ because it is produced from granulated blast furnace slag as opposed to clinkering process in cement, thus greatly reducing $\mathrm{CO}_{2}$ release [6], [7].The addition of GGBS in cement improves the pore structure of cement paste, reduces its permeability and increases sulfate attack resistance, workability and compressive strength in concrete. This makes it possible to obtain betterperforming long-life mortar products. Generally, GBFS contains considerable amounts of $\mathrm{SiO}_{2}$ and $\mathrm{CaO}$, which 
makes it pozzolanic with cementing characteristic $[8,9]$. The alkali-activated cement is classified based on phase composition of the hydration products: $\mathrm{R}-\mathrm{A}-\mathrm{S}-\mathrm{H}\left(\mathrm{R}=\mathrm{Na}^{+}\right.$or $\left.\mathrm{K}^{+}\right)$in the aluminosilicate based systems and R-C-A-S-H in the alkali-activated slag or Portland cements [10]. The alkaline activators can be sodium hydroxide $(\mathrm{NaOH})$, potassium hydroxide $(\mathrm{KOH})$, sodium silicate $\left(\mathrm{Na}_{2} \mathrm{SiO}_{3}\right)$ and potassium silicate $\left(\mathrm{K}_{2} \mathrm{SiO}_{3}\right)$ for the activation of aluminosilicate materials. The slag-based geopolymer is considered to have high early strength and greater acid resistance [11]. The basic idea of this work is the possible use two types different alkali activator for preparing non cement binder, where original raw materials used granulated blast furnace slag from metallurgy production. At prepared samples were tested compressive strength and bulk density after 2,7 and 28 days. Further was describes hydration process of prepared samples.

\section{MATERIALS}

The original material, granulated blast furnace slag (GBFS), was produced by Liberty Ostrava a.s. The GBFS was milled in the company Kotouč Štramberk, LB Cemix, s.r.o. Blaine fineness of slag is $380 \mathrm{~m}^{2} . \mathrm{kg}^{-1}$. Two types of activators were used for slag activation: sodium water glass ( $\mathrm{NaOH})$ (KITTFORT Praha s.r.o.) and solid $\mathrm{Na}_{2} \mathrm{SiO}_{3}$ (PENTA s.r.o). Adjusted silicate modulus was $\mathrm{Ms}=1$. The composition of mixtures MX-L and MX-S (see Table 1). Mixtures amount of $100 \mathrm{wt} . \%$ GBFS with two different types of alkali activator and different percentages of distilled water. It is important that all particles are in contact with the alkali activator. The mixtures were homogenized in a ball mill during 20 minutes. Size of the prepared samples was $20 \times 20 \times 20$ $\mathrm{mm}$ and the samples were hydrated for 24 hours in a hydration vacuum box at room temperature. After 24 hours, samples were removed from the form and the hydration process continued for several more days.

Table 1 Composition of prepared mixtures

\begin{tabular}{|c|c|c|c|c|c|c|c|}
\hline \multirow{2}{*}{ Mixtures } & \multirow{2}{*}{$\begin{array}{c}\text { Type of } \\
\text { alkali } \\
\text { activator }\end{array}$} & \multirow{2}{*}{$\begin{array}{c}\text { Amount of } \\
\text { GBFS (g) }\end{array}$} & \multirow{2}{*}{$\begin{array}{c}\text { Ratio } \\
\mathrm{Na}_{2} \mathrm{O}(\%)\end{array}$} & \multicolumn{2}{|c|}{$\begin{array}{c}\text { Amount of alkali } \\
\text { activators }\end{array}$} & \multicolumn{2}{c|}{ Water for activator } \\
\cline { 5 - 8 } & & & liquid (ml) & solid (g) & liquid (ml) & solid (g) \\
\hline MX-L & liquid & 300 & 5 & 59.7 & - & 33.4 & - \\
\hline MX-S & solid & 300 & 5 & - & 28.9 & - & 90 \\
\hline
\end{tabular}

\section{CHARACTERIZATION METHODS}

GBFS chemical composition was determined using energy dispersive fluorescence spectrometer SPECTRO XEPOS equipped with 50 Watt Pd X-ray tube (Spectro). Phase composition of the sample was characterized using a Bruker D8 Advance x-ray powder diffractometer (Bruker AXS). The characterization of the thermal behavior of the GBFS was performed on TG/DCS analyzer STA504 (TA Instruments). The sample of scale placed in an aluminum crucible was analyzed for temperatures ranging from $21^{\circ} \mathrm{C}$ to $1,100{ }^{\circ} \mathrm{C}$ in a dynamic atmosphere of $\mathrm{N}_{2}\left(5 \mathrm{I} \cdot \mathrm{h}^{-1}\right)$, the heating rate was $10 \mathrm{~K} \cdot \mathrm{min}^{-1}$. Homogenization of the raw materials was performed using ball mill (Brio Hranice s.r.o.). Particle size distribution (PSD) of the scale was analyzed on the equipment Mastersizer (Malvern Panalytical Ltd., Malvern, UK). Specific surface areas were measured using Sorptomatic 1990 (Thermo Fisher Scientific, USA), employing the BET methodology.

\section{RESULT AND DISCCUSION}

The main phase of $X R D$ record presented quartz $\mathrm{SiO}_{2}$, merwinite $\mathrm{Ca}_{3} \mathrm{Mg}\left(\mathrm{SiO}_{4}\right)_{2}$ and akermanite $\mathrm{Ca}_{2} \mathrm{MgSi}_{2} \mathrm{O}_{7}$. Chemical composition of GBFS is presented in Table 2. The majority components of GBFS are CaO $56.96 \%$ and $\mathrm{SiO}_{2}$ with $21.45 \%$ and $\mathrm{Al}_{2} \mathrm{O}_{3}$ with $5.58 \%$. Main oxides account for about 84 wt.\%. It is possible to recalculate the content of $\mathrm{CaO}, \mathrm{SiO}_{2}$, and $\mathrm{Al}_{2} \mathrm{O}_{3}$ to theoretical basis $100 \%$ of this slag in the ternary phase diagram of $\mathrm{CaO}-\mathrm{SiO}-\mathrm{Al}_{2} \mathrm{O}_{3}$. The position of points corresponds to slag composition and with equilibrium phase association of three minerals (C, S, A). In Figure 1 the area of composition of GBFS is marked. The amount 
of $\mathrm{CaO}$ is higher than that of $\mathrm{SiO}_{2}$. Slag has a low viscosity. Rapid cooling of slag support formed glass. Glass form is predestined for latent hydration of slag.

Table 2 Chemical composition of granulated blast furnace slag

\begin{tabular}{|c|c|c|c|c|c|c|c|c|c|c|c|c|c|}
\hline $\begin{array}{c}\text { Chemical } \\
\text { composition }\end{array}$ & $\mathrm{Na}_{2} \mathrm{O}$ & $\mathrm{MgO}$ & $\mathrm{Al}_{2} \mathrm{O}_{3}$ & $\mathrm{SiO}_{2}$ & $\mathrm{SO}_{3}$ & $\mathrm{Cl}$ & $\mathrm{K}_{2} \mathrm{O}$ & $\mathrm{CaO}$ & $\mathrm{TiO}_{2}$ & $\mathrm{Cr}_{2} \mathrm{O}_{3}$ & $\mathrm{MnO}$ & $\mathrm{Fe}_{2} \mathrm{O}_{3}$ & $\mathrm{LOI}$ \\
\hline (wt.\%) & 0.19 & 6.56 & 5.58 & 25.45 & 1.77 & 0.03 & 0.56 & 56.96 & 0.50 & 0.04 & 0.98 & 0.61 & 0.58 \\
\hline
\end{tabular}

Hydraulic reactivity of slag depends on chemical composition, glass phase percentage, particle size and morphology. Slag is a latent hydraulic material, without alkali activator it is not reactive with water and hydration process is very slow. One of the most important characteristics of slag composition for use in binders is the ratio between $\mathrm{CaO}$ and $\mathrm{SiO}_{2}$ content. Hydraulic activity is defined by the percentage of the main oxides in materials and by modulus. Modulus of basicity $M_{b}=(\mathrm{CaO}+\mathrm{MgO}) /\left(\mathrm{SiO}_{2}+\mathrm{Al}_{2} \mathrm{O}_{3}\right)$. For the tested slag, $M_{b}=2.04$. It is basicity slag. In the case of acid slag the value is $M_{b}<1$. Modulus of activity is expressed $M_{a}=\mathrm{Al}_{2} \mathrm{O}_{3} / \mathrm{SiO}_{2}$ and for the tested slag $M_{a}=0.21$. Hydraulic activity of slag grows with growing modulus of basicity $M_{b}$ and growing modulus of activity $M_{a}$. Another possibility to measure slag quality is to use the so called quality coefficient $\mathrm{K}_{\mathrm{k}}=\mathrm{CaO}+\mathrm{MgO}+\mathrm{Al}_{2} \mathrm{O}_{3} / \mathrm{SiO}_{2}+\mathrm{MnO}$ [7]. The value of $K_{k}=2.6$ for tested GBFS. Slag with $K_{k}>1.9$ is more active because the value $K_{k}>1.9$ signifies low activity [12].

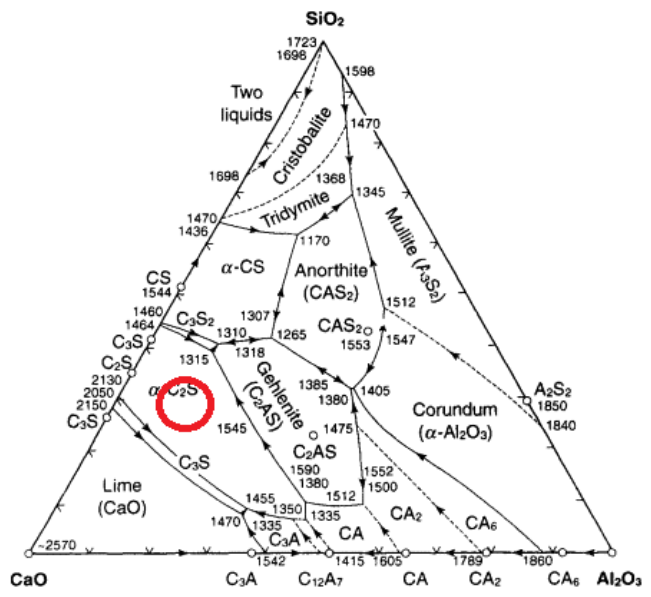

Figure 1 Ternary diagram $\mathrm{CaO}-\mathrm{Al}_{2} \mathrm{O}_{3}-\mathrm{SiO}_{2}$ with drawing area equilibrium of blast slag [13]

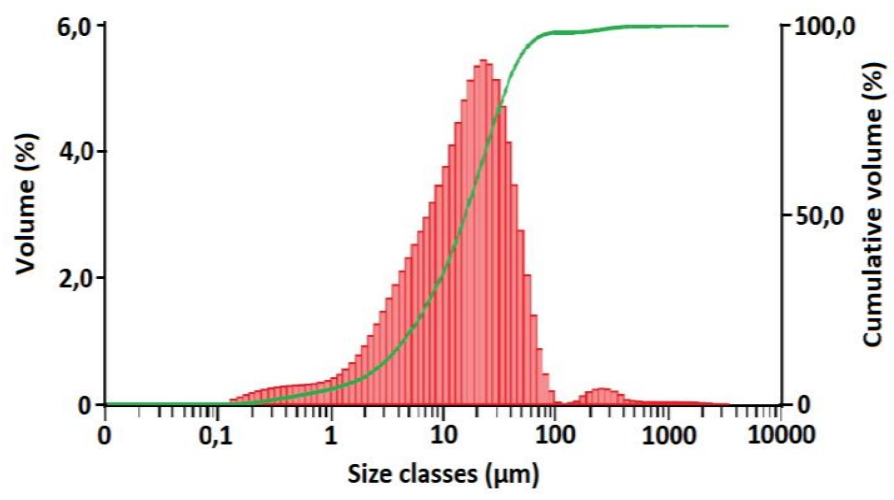

Figure 2 The curve of granulometry GBFS

Particle size distribution of the GBFS is $D_{(10)}=2.71 \mu \mathrm{m} D_{(50)}=15.8 \mu \mathrm{m}$ and $D_{(90)}=45.2 \mu \mathrm{m}$, see (Figure 2). Granulometry and Blaine fineness led to an increase in mechanical strength of activated slag where Blaine fineness from 3,320 to $5,500 \mathrm{~cm}^{2} / \mathrm{g}$ [14] or [15] activated slag depends on the type of slag: 4,000 and $5,500 \mathrm{~cm}^{2} / \mathrm{g}$ for basic slag and 4,500-6,500 $\mathrm{cm}^{2} . \mathrm{g}^{-1}$ for acid and neutral slags. The use of solid and liquid activator has an effect on the hydration process. Author [16] used solid water glass, $\left(\mathrm{Na}_{2} \mathrm{SiO}_{3} \cdot 5 \mathrm{H}_{2} \mathrm{O}\right)$ as slag activator and important factor for fast reactivity, in which the small slag particles $(<2 \mu \mathrm{m})$ were completely hydrated within the first $24 \mathrm{~h}$ after mixing, whereas hydration of larger particles was much slower.

Characterization of the thermal behavior of the GBFS was performed on a TG/DCS analyzer (Figure 3). Reaction changes and weight losses occurring in GBFS hydrated samples were determined by DTA and TG analysis. Samples of GBFS after 28 days of hydration under the same conditions were ground to fine powder and their hydration was stopped with acetone. Then the samples were placed in a corundum crucible and heated in air at a rate of $15{ }^{\circ} \mathrm{C} \cdot \mathrm{min}^{-1}$. The first endothermic peak is between $35-295^{\circ} \mathrm{C}$ with a maximum peak 
at $150^{\circ} \mathrm{C}$. Dehydration of the sample is assumed here. The second exothermic peak in the range of 755$855^{\circ} \mathrm{C}$ with a peak of $810^{\circ} \mathrm{C}$ will be due to the formation of new phases. Total GBFS weight loss is about $20 \%$ complete at $810^{\circ} \mathrm{C}$.

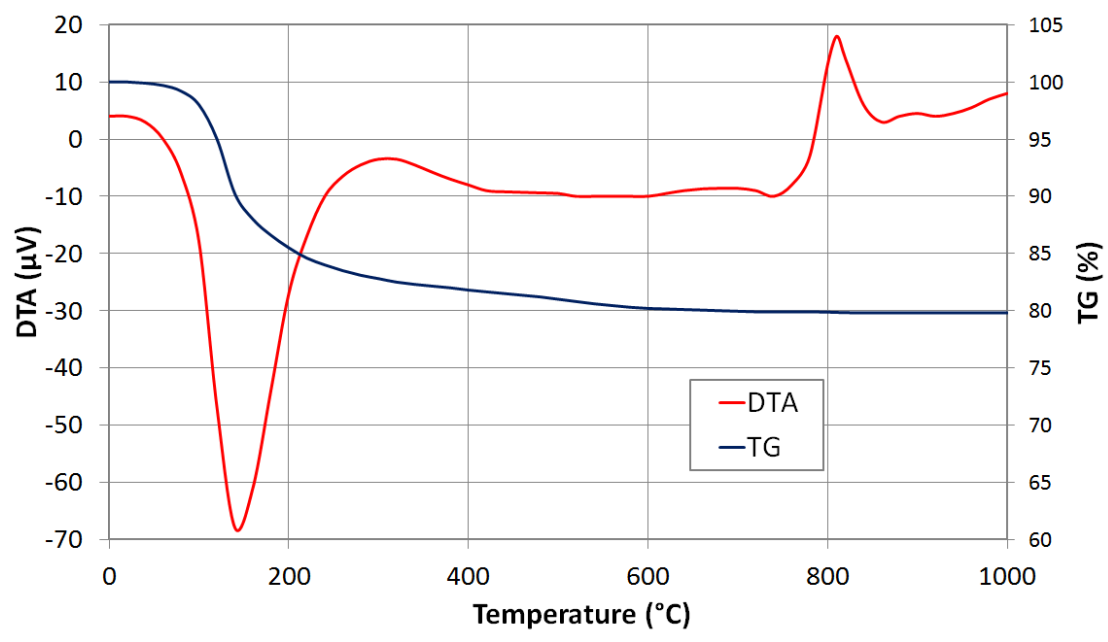

Figure 3 TG/DTA curves registered for granulated blast furnace slag (GBFS)

The effect of C-S-H phase on the geopolymerization of aluminosilicates has been studied with a view to know its role in early age strength [17]. Compressive strength and bulk density were evaluated on the mixtures after 2, 7 and 28 days, see Table 3. The compressive strength increased in both mixtures MX-L and MX-S with hydration time. This confirmed the assumption that GBFS, by reaction with the activator, causes the formation of $\mathrm{CSH}$ phases which contribute to high strengths. In sample MX-L, compressive strength reached $116 \mathrm{MPa}$ after 28 days and in sample MX-S after 28 day is $74 \mathrm{MPa}$.

Table 3 Compressive strength of prepared samples ML and MS

\begin{tabular}{|c|c|c|c|c|}
\hline \multirow{2}{*}{$\begin{array}{c}\text { Time of hydration of } \\
\text { samples (day) }\end{array}$} & \multicolumn{2}{|c|}{ Compressive strength (MPa) } & \multicolumn{2}{c|}{ Bulk density (kg.m $\mathbf{m}^{-3}$ ) } \\
\cline { 2 - 5 } & MX-L & MX-S & MX-L & MX-S \\
\hline 2 & 51.3 & 46.7 & 2,036 & 1,951 \\
\hline 7 & 86.3 & 60.0 & 2,004 & 1,923 \\
\hline 28 & 116.7 & 74.2 & 2,000 & 1,900 \\
\hline
\end{tabular}

The compressive strength of samples with solid activator gradually increases. The effect of liquid alkaline activator is more pronounced than the use of solid activator. In both cases strengths comparable with commercially produced blast furnace slag cement (slag cement) i.e. CEMIII/32.5 are achieved. The parameters of bulk densities for mixtures MX-L and MX-S have a decreasing tendency. For sample MX-S, the bulk density is much lower compared to both sample MX-L and other samples. This fact may be due to the solid alkaline activator used, which does not support an intensive hydration process. The increase in strength was originally connected to the effects of pores filling, structuring of poorly arranged microstructure and twin creations formed during extremely polymerized units of alkali-activation and calcium silicate hydrate $(\mathrm{C}-\mathrm{S}-\mathrm{H}) \mathrm{gels}$, [14]. The optimum amount of activator dosage, in terms of $\mathrm{Na}_{2} \mathrm{O}$ by the mass of slag, varies from $3 \%$ to $5.5 \%$ and using water glass with a silica modulus of 1-1.5 leads to higher mechanical strengths [15]. Compressive strength of 60 and $150 \mathrm{MPa}$ for slag concretes activated by water glass were achieved without heat treatment or special additives [18].

Hydration processes were investigated of original GBFS. GBFS samples after 28 days of hydration were annealed at $100^{\circ} \mathrm{C}, 200^{\circ} \mathrm{C}$ and $300^{\circ} \mathrm{C}$ (see Table 4). At the beginning and after each annealing, the samples 
were measured and weighed, from which weight loss was calculated. These hydrates decompose to $300{ }^{\circ} \mathrm{C}$. Weight loss $\Delta \mathrm{m} 100{ }^{\circ} \mathrm{C}=1.37 .10^{-3} \mathrm{~kg}$ at $\Delta \mathrm{m} 200^{\circ} \mathrm{C}=2.76 \cdot 10^{-3} \mathrm{~kg}$ and $\Delta \mathrm{m} 300{ }^{\circ} \mathrm{C}=3.39 .10^{-3} \mathrm{~kg}$.

Table 4 Bulk density of samples after different temperature treatment

\begin{tabular}{|c|c|}
\hline Sample (1) & Bulk density $\mathbf{~ ( k g . ~} \mathbf{~}^{-\mathbf{3}}$ ) \\
\hline BD original (RT) & 1,947 \\
\hline BD $100^{\circ} \mathrm{C}$ & 1,818 \\
\hline $\operatorname{BD~} 200^{\circ} \mathrm{C}$ & 1,665 \\
\hline $\operatorname{BD} 300^{\circ} \mathrm{C}$ & 1,583 \\
\hline
\end{tabular}

Bulk density of original GBFS was evaluated after 28 days in different temperature cycles. The decrease in bulk density in the sample is connected with drying temperature, or annealing. The first step is releasing "free" water (water from the pores of the samples), the second step is decomposition of C-S-H phases at higher temperatures. Sample shrinkage does not occur, therefore water release is connected with weight changes and BD decreases continuously.

\section{CONCLUSION}

Non-cement binder "granulated blast furnace slags binder" can be prepared with the use of liquid and solid alkali activator. Advantages and disadvantages: due to its consistency, water glass is suitable for better mixing of individual components, the advantage of solid activator $\left(\mathrm{Na}_{2} \mathrm{SiO}_{3}\right)$ is easier handling in the preparation of mixtures, the disadvantage is worse reactivity of mixtures. These problems can be partly eliminated by homogenizing the mixtures in a suitable milling device. Different hydration processes were found at the determined compressive strength and bulk density. The results are comparable with commercial slag cement. Faster hydration and thus the growth of strength occurs in mixtures with a liquid activator - water glass. Solid - powder activator with the same treatment $\mathrm{Ms}$ and in the same dose of $\mathrm{Na}_{2} \mathrm{O}$ causes a slow down in the hydration process, probably due to more complex processes in the dissolution of $\mathrm{Na}_{2} \mathrm{SiO}_{3}$ in the mixing water.

\section{ACKNOWLEDGEMENTS}

This work was supported by the Ministry of Education, Youth and Sports of the Czech Republic under Project No. (CZ.02.1.01/0.0/0.0/17_049/0008426) - Research of waste management of materials and by-products from metallurgical and related industry plants, No. (SP2020/34) - Low-energy systems and materials in industrial technologies, No. (SP2020/39) - Specific research in the metallurgical, materials and process engineering. The MasterSizer 3000 particle size analyzer (Malvern) was acquired within the "Development of research and development basis of RMSTC" project (No. CZ.1.05/2.1.00/19.0387) within the frame of the operational program "Research and Development for Innovations" financed by structural funds and the state budget of the Czech Republic.

\section{REFERENCES}

[1] Global Slag News [online]. [viewed 2020-05-10]. Available from: https://www.globalslag.com/news.

[2] MAJHI, R.K., NAYAK, A.N. Production of sustainable concrete utilising high-volume blast furnace slag and recycled aggregate with lime activator. Journal of Cleaner Production. 2020, vol. 255. [viewed 2020-05-10]. Available from: https://doi.org/10.1016/j.jclepro.2020.120188.

[3] OVČAČíKOVÁ, H., VLČEK, J., KLÁROVÁ, M., TOPINKOVÁ, M. Metallurgy dusts as a pigment for glazes and engobes. Ceramics International. 2017, vol. 10, pp.7789-7796. 
[4] Statista [online]. [viewed 2020-05-12]. Available from: https://www.statista.com/statistics/219343/cementproduction-worldwide.

[5] SHI, C., JIMINEZ, A.F., PALOMO, A. New cements for the 21st century: the pursuits of an alternative to Portland cement. Cement and Concrete Research. 2011, vol. 41, no. 7, pp. 750-763.

[6] FLOWER, D.J.M., SANJAYAN, J.G. Greenhouse gas emissions due to concrete manufacture. International Journal of Life Cycle Assessment. 2007, vol. 12, no. 5, pp.282-288.

[7] THOMAS, M.D.A., HOOTON, R.D., SCOTT, A., ZIBARA, H. The effect of supplementary cementitious materials on chloride binding in hardened cement paste. Cement and Concrete Research. 2012, vol. 42, no. 1, pp. 1-7.

[8] LI, C., SUN, H., LI, L. A review: The comparison between alkali-activated slag ( $\mathrm{Si}+\mathrm{Ca})$ and metakaolin ( $\mathrm{Si}+\mathrm{Al})$ cements. Cement and Concrete Research. 2010, vol. 40, pp. 1341-1349.

[9] LEE, N., KIM, E., LEE, H. Mechanical properties and setting characteristics of geopolymer mortar using styrenebutadiene (SB) latex. Construction and Building Materials. 2016, vol. 113, pp. 264-272.

[10] KRIVENKO, P.V., KOVALACHUK, G.Yu. Directed synthesis of alkaline aluminosilicate minerals in a geocement matrix. Journal of Materials Science. 2007, vol. 42, no. 9, pp. 2944-2953.

[11] SINGH, B., ISHWARYA G., GUPTA, M., BHATTACHARYYA, S.K. Geopolymer concrete: A review of some recent developments. Construction and Building Materials. 2015, vol. 85, pp. 78-90.

[12] SHI, C., KRIVENKO, P. V., ROY, D. Alkali-aktivated cements and concretes. Abingdon: Taylor\& Francis, 2006, 370 pp. ISBN 10:0-415-70004-3.

[13] MACPHEE, D.E., LACHOWSKI, E. Lea's Chemistry of Cement and Concrete (4th Edition). ButterworthHeinemann, 2003. ISBN 978-0-7506-6256-7.

[14] BROUGH, A.R., ATKINSON, A. Sodium silicate-based, alkali-activated slag mortar: Part 1. Strength, hydration and microstructure. Cement and Concrete Research. 2002, vol. 32, no. 6, pp. 865-879.

[15] WANG, S.D, SCRIVENER, K.L., PRATT, P.L. Factors affecting the strength of alkali-activated slag. Cement and Concrete Research. 1994, vol. 24, pp. 1033-1043.

[16] GRUSKOVNJAK, A., LOTHENBACH, B., HOLZER, L., FIGI, R., WINNEFELD, F. Hydration of alkali-activated slag: comparison with ordinary Portland cement. Advances in Cement Research. 2006, vol. 18, no. 3, pp. 119128.

[17] YIP, C.K., LUCKEY, G.C, DEVENTURE, J.S.V. van. The coexistence of geopolymeric gel and calcium silicate hydrate at the early stage of alkaline activation. Cement and Concrete Research. 2005, vol. 35, no. 9, pp. 16881697.

[18] ESCALANTE CARCIA, J.I., CAMPOS-VENEGAS, K., GOROKHOVSKY, A., FERNANDEZ, A. Cementitious composites of pulverised fuel ash and blast furnace slag activated by sodiumsilicate: effect of $\mathrm{Na}_{2} \mathrm{O}$ concentration and modulus. Advances in Applied Ceramics. 2006, vol. 105, no. 4, pp. 201-208. 